\title{
Effect of Core Thickness and Core Density on Low Velocity Impact Behavior of Sandwich Panels with PU Foam Core
}

\author{
Sunith Babu Loganathan', Hanumanahally Kambada Shivanand ${ }^{2}$ \\ ${ }^{1}$ Department of Mechanical Engineering, M. S. Ramaiah Institute of Technology, Bangalore, India \\ ${ }^{2}$ Department of Mechanical Engineering, University Visvesvaraya College of Engineering, Bangalore, India \\ Email: sunithbabu@msrit.edu
}

Received 8 April 2015; accepted 28 April 2015; published 4 May 2015

Copyright (C) 2015 by authors and Scientific Research Publishing Inc.

This work is licensed under the Creative Commons Attribution International License (CC BY). http://creativecommons.org/licenses/by/4.0/

(c) (i) Open Access

\begin{abstract}
Composite sandwich structures are highly proven materials that provide high strength to weight ratio. However research works are still being carried out in the area of impact characteristics of sandwich composites. This paper provides a better understanding on the effect of core density and core thickness of sandwich panels subject to low velocity drop test. Specific energy absorption capacity of sandwich panels is obtained and factors affecting the same are explored with facings made of woven glass fiber laminates and polyurethane foam core with three different densities of $70 \mathrm{Kg} / \mathrm{m}^{3}, 100 \mathrm{Kg} / \mathrm{m}^{3}, 200 \mathrm{Kg} / \mathrm{m}^{3}$.
\end{abstract}

\section{Keywords}

Sandwich Panels, Polyurethane Foam, Specific Energy Absorption Factor, Low Velocity Impact Test

\section{Introduction}

Sandwich composites are used in various fields of engineering, ranging from basic consumer application to advanced aerospace industries, mainly due to the fact that they attain good weight reduction and have high strength to weight ratio [1]. Much of the research work was carried out in the past related to low velocity impact behavior of aluminum foam core sandwich composites [2]-[6]. Although the impact properties were improved by using an aluminum foam core, this also resulted in marginal increase in weight. Further studies have also been carried out that, using composite materials as facings not only improved the performance of the sandwich composites, but also enabled reduction in weight [7]. Sandwich structures as part of flight hull may have different impacts such as bird hit, ballistic impact and debris encountered during run way. These types of impact are classified as 
high velocity and much of the research has been carried out [8]-[10]. In case of aerospace applications, sandwich structures made from polymer facings and foam core are preferred, since this combination not only reduces the overall weight of the composite, but also enhances the stiffness to weight ratio. With minor impact on the sandwich structures, their functional properties are altered as they are specifically developed using high precision technique. Hence, studies on low velocity impact behavior on aerospace application are very essential. Although much of the research has been done on Rohacell and PVC based foams as core material for sandwich composites [11]-[13], very limited research has been carried out on polyurethane based foam core sandwich composites subject to low velocity impact. One main issue with low velocity impact is the visibility of impacted region (BVID = Barely Visible Impact Damage). This damage results in delamination, fiber failure, face core debonding and core crushing developed due to impact forces [14]. This paper provides the effect of thickness \& density of core and height of fall on specific energy absorption capacity of sandwich composites made from PU based foams with FRP facings. Further interior and exterior damages resulting from low velocity impact are studied by conducting the experiments on an instrumented drop weight impact test machine with different heights of fall.

\section{Experimental}

\subsection{Fabrication of Sandwich Panels}

The sandwich panel facings are made from bi-woven-glass fabric laminates. The fabric is made from E-glass fiber 7628 cloth. The face sheets are made of $0^{\circ} / 90^{\circ}$ with fiber orientation parallel to the sides of the panel. The thickness of the facings are kept constant with $1 \mathrm{~mm}$ on the top and bottom of the sandwich composite. The core is made of polyurethane foam with different density $\left(70 \mathrm{~kg} / \mathrm{m}^{3}, 100 \mathrm{~kg} / \mathrm{m}^{3}, 200 \mathrm{~kg} / \mathrm{m}^{3}\right)$. Most of the aerospace application falls in this range of density selected [15]. The young's modulus for the facings and cores of different density are listed in Table 1 and the elastic properties of $\mathrm{E}$ glass are shown in Table 2. Two different foam thicknesses were used to find their influence on impact properties of sandwich panels.

The sandwich panels were fabricated in room temperature by bonding the glass fiber laminate and polyurethane foam core material with LY556 epoxy resin mixed with HY951 hardener in the ratio of 10:1. The face-sheets which were $1 \mathrm{~mm}$ thick and cores of different thickness were bonded together by vacuum bagging technique as shown in Figure 1. The sandwich panels were later cut into $150 \mathrm{~mm} \times 150 \mathrm{~mm}$ dimensions with two thicknesses of $12 \mathrm{~mm} \& 16 \mathrm{~mm}$ respectively. The sandwich panels were carefully fabricated to ensure perfect bonding between laminate and foam core. The specimen were coded as shown in Table 3 and Figure 2, in order to ensure better understanding of specimen type for various impact tests. The experiments were conducted for three trials for every combination of sandwich composite to ensure repeatability.

Table 1. Young's modulus for different PU foam core thickness [16] [17].

\begin{tabular}{ccc}
\hline Density PU Foam $\left[\mathrm{Kg} / \mathrm{m}^{3}\right]$ & Young's Modulus $[\mathrm{MPa}]$ & Foam Thickness $[\mathrm{mm}]$ \\
\hline 70 & 12.3 & 10,14 \\
100 & 32.69 & 10,14 \\
200 & 86.88 & 10,14 \\
\hline
\end{tabular}

Table 2. Elastic properties of the bi-owen FRP facings.

\begin{tabular}{cccccccccccc}
\hline $\mathrm{E}_{1}(\mathrm{GPa})$ & $\mathrm{E}_{2}(\mathrm{GPa})$ & $\mathrm{E}_{3}(\mathrm{GPa})$ & $\mathrm{G}_{12}(\mathrm{GPa})$ & $\mathrm{G}_{23}(\mathrm{GPa})$ & $\mathrm{G}_{13}(\mathrm{GPa})$ & $v_{12}$ & $v_{23}$ & $v_{13}$ \\
\hline 16.76 & 16.76 & 7.69 & 2.41 & 2.29 & 2.29 & 0.15 & 0.45 & 0.45 \\
\hline
\end{tabular}

Table 3. Specimen designation.

\begin{tabular}{cccc}
\hline Specimen Coding & Core Density $\left[\mathrm{Kg} / \mathrm{m}^{3}\right]$ & Core Thickness $[\mathrm{mm}]$ & GFRP Facings (Top \& Bottom) $[\mathrm{mm}]$ \\
\hline G1, G2, G3 & 70 & 10 & 1 \\
G4, G5, G6 & 100 & 10 & 1 \\
G7, G8, G9 & 200 & 10 & 1 \\
G11, G12, G13 & 70 & 14 & 1 \\
G14, G15, G16 & 100 & 14 & 1 \\
G17, G18, G19 & 200 & 14
\end{tabular}




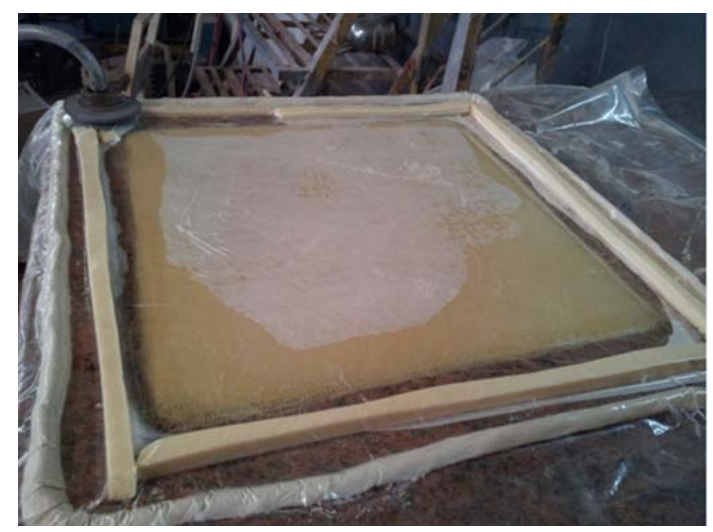

Figure 1. Vacuum bagging technique of sandwich panels.

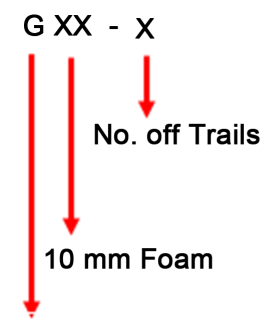

Glass Fiber

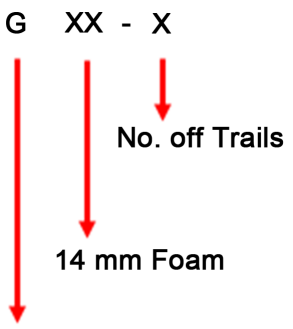

Glass Fiber

Figure 2. Generalized coding of specimen.

\subsection{Low-Velocity Impact Test}

Instrumented Drop tests were conducted on the sandwich specimen (Figure 3) for different impact velocities $(1.401 \mathrm{~m} / \mathrm{sec}, 2.426 \mathrm{~m} / \mathrm{sec}$, and $3.123 \mathrm{~m} / \mathrm{sec})$ on 18 possible combination of different core thickness and height of fall that has been recorded and is shown in Table 4 and Table 5 . The indenter size and shape, boundary condition was similar to that of quasi-static tests at room temperature. The indenter used for the test is made of hemispherical nose-shape with a diameter of $12.7 \mathrm{~mm}$. Impactor mass of $2.5 \mathrm{Kg}, 5 \mathrm{Kg} \& 10 \mathrm{Kg}$ was used for the impact test with different thickness \& core densities. The height of fall was varied from $100 \mathrm{~mm}$ to $500 \mathrm{~mm}$.

\section{Experimental Results}

For better understanding purpose, only two sets of specimens were selected to show the Energy Absorption at Max Load (J), namely G1, G2, G3 \& G3, G6, G9 and Energy vs. Time plot was drawn as shown in Figure 4. Each of the Sandwich Panels G1, G2, and G3 were subjected to a fall of different heights as listed in Table 4. It is clear that as the thickness of the sandwich panels was kept constant along with density being same, the Energy Absorption at Max Load increased mainly due to the fact that the height of fall was increased. The blue curve depicts less energy absorption since the height of fall was only $0.1 \mathrm{~m}$ while the green curve had higher energy absorption since the height of fall was increased to $0.5 \mathrm{~m}$. Further as the height of fall was increased, Impact force increased and the same was observed in the G3 sample as the indenter had to pass through the facings, foam and finally dent the lower part of the facings. The next set of samples selected were G3, G6, G9 the variation of Energy vs. Time plot was drawn keeping the height of fall constant and varying the Density of the foam. This also resulted in increased Energy Absorption Capacity for the same thickness and material properties as shown in Figure 5.

\section{Specific Energy Absorption Factor}

The experimental results made it clear that the effect of core density had a significant role in specific energy absorption and impact energy factor. Both increased with increase in core density and also core thickness as shown in Figure 6 and Figure 7 for both $10 \mathrm{~mm}$ and $14 \mathrm{~mm}$ core thickness. 


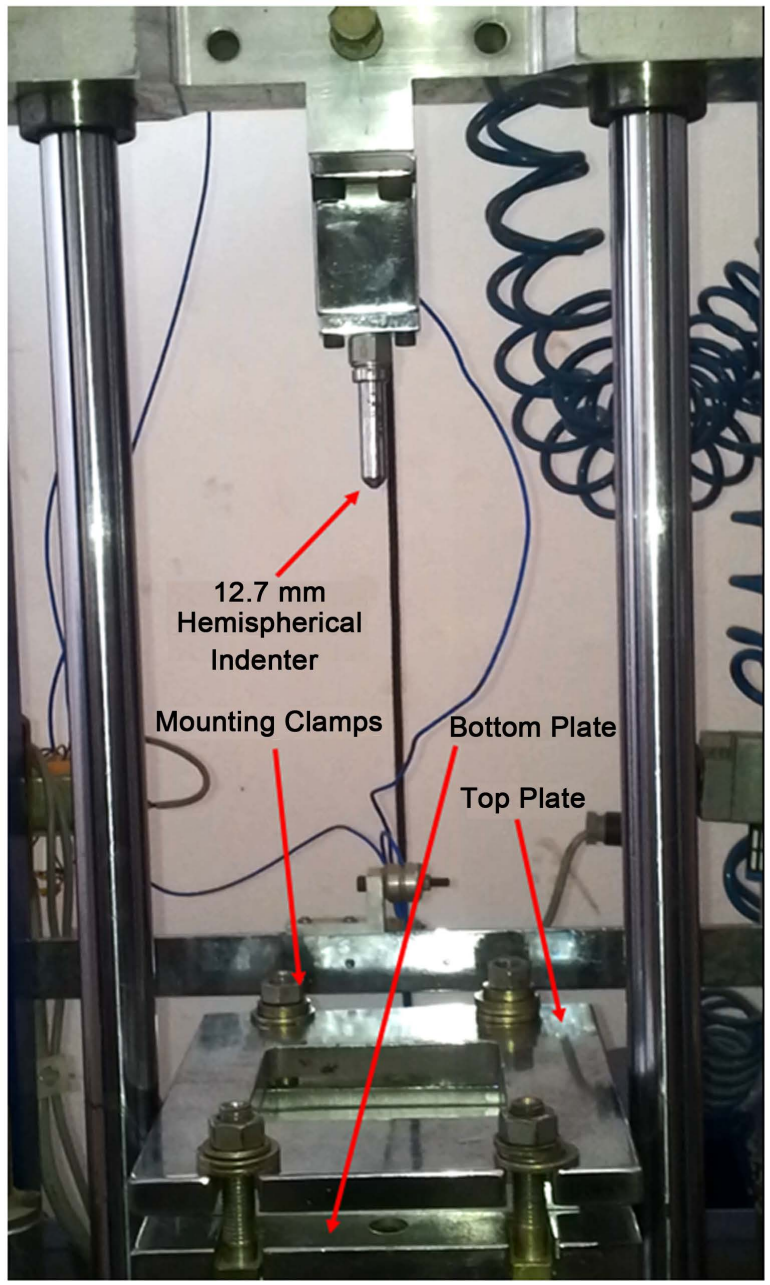

Figure 3. Low velocity impact testing machine.

Energy at Max Load for $70 \mathrm{Kg} / \mathrm{m}^{3}$

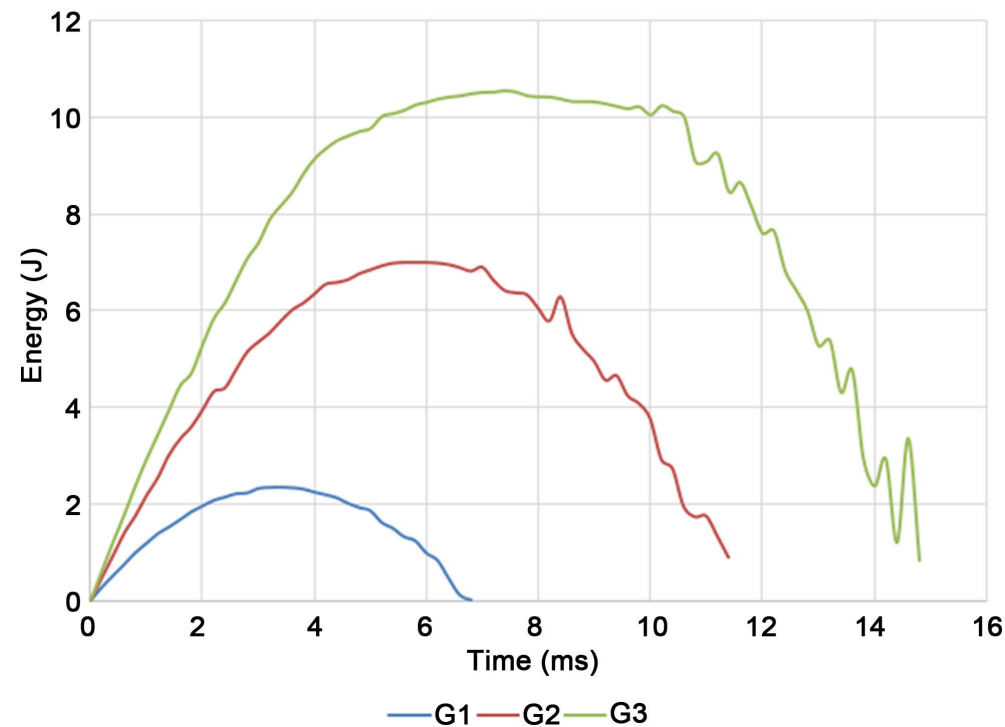

Figure 4. Energy vs. Time (ms) plot for $70 \mathrm{Kg} / \mathrm{m}^{3}$ panel. 


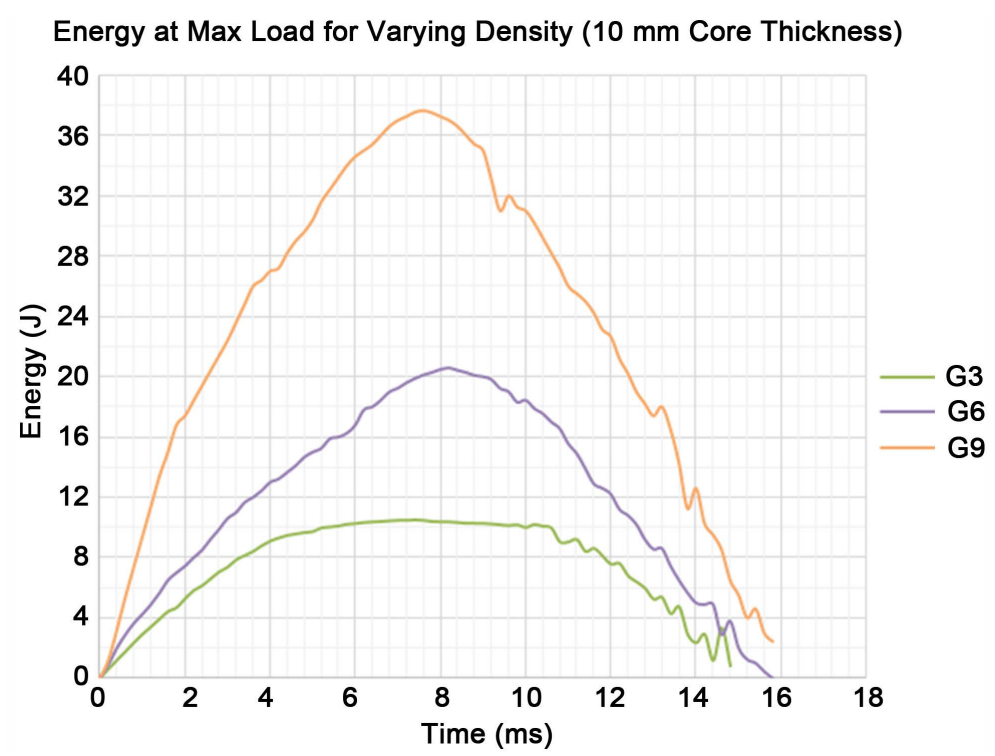

Figure 5. Energy vs. Time plot for $0.5 \mathrm{~m}$ fall.

Table 4. Experimental values for different impact velocities and $10 \mathrm{~mm}$ core thickness.

\begin{tabular}{|c|c|c|c|c|c|c|c|}
\hline $\begin{array}{l}\text { Specimen } \\
\text { Code }\end{array}$ & $\begin{array}{c}\text { Core Density } \\
{\left[\mathrm{Kg} / \mathrm{m}^{3}\right]}\end{array}$ & $\begin{array}{c}\text { Mass of Panel } \\
{[\mathrm{Kg}]}\end{array}$ & $\begin{array}{c}\text { Impact Velocity } \\
{[\mathrm{mm}]}\end{array}$ & $\begin{array}{l}\text { Impact } \\
\text { Energy }\end{array}$ & $\begin{array}{c}\text { Max } \\
\text { Load [N] }\end{array}$ & $\begin{array}{c}\text { Energy at } \\
\text { Max Load [J] }\end{array}$ & $\begin{array}{l}\text { Specific Energy } \\
\text { Absorption }[\mathrm{J} / \mathrm{Kg}]\end{array}$ \\
\hline G1 & 70 & 0.14 & 1.401 & 2.45 & 1160 & 2.34 & 16.71 \\
\hline G2 & 70 & 0.14 & 2.426 & 7.36 & 1190 & 7.00 & 50.01 \\
\hline G3 & 70 & 0.14 & 3.132 & 12.26 & 1230 & 10.53 & 75.21 \\
\hline G4 & 100 & 0.22 & 1.401 & 4.90 & 1185 & 4.33 & 19.68 \\
\hline G5 & 100 & 0.22 & 2.426 & 14.71 & 1210 & 13.76 & 58.85 \\
\hline G6 & 100 & 0.22 & 3.132 & 24.52 & 1270 & 20.58 & 93.54 \\
\hline G7 & 200 & 0.31 & 1.401 & 9.81 & 1201 & 8.23 & 26.50 \\
\hline G8 & 200 & 0.31 & 2.426 & 29.43 & 1228 & 22.12 & 71.35 \\
\hline G9 & 200 & 0.31 & 3.132 & 49.05 & 1312 & 37.64 & 121.41 \\
\hline
\end{tabular}

Table 5. Experimental values for different impact velocities and $14 \mathrm{~mm}$ core thickness.

\begin{tabular}{cccccccc}
\hline $\begin{array}{c}\text { Specimen } \\
\text { Code }\end{array}$ & $\begin{array}{c}\text { Core Density } \\
{\left[\mathrm{Kg} / \mathrm{m}^{3}\right]}\end{array}$ & $\begin{array}{c}\text { Mass of } \\
\text { Panel }[\mathrm{Kg}]\end{array}$ & $\begin{array}{c}\text { Impact Velocity } \\
{[\mathrm{mm}]}\end{array}$ & $\begin{array}{c}\text { Impact } \\
\text { Energy }\end{array}$ & $\begin{array}{c}\text { Max Load } \\
{[\mathrm{N}]}\end{array}$ & $\begin{array}{c}\text { Energy at } \\
\text { Max Load }[\mathrm{J}]\end{array}$ & $\begin{array}{c}\text { Specific Energy } \\
\text { Absorption }[\mathrm{J} / \mathrm{Kg}]\end{array}$ \\
\hline G11 & 70 & 0.14 & 1.401 & 2.45 & 1220 & 2.41 & 7.21 \\
G12 & 70 & 0.14 & 2.426 & 7.36 & 1260 & 7.24 & 51.71 \\
G13 & 70 & 0.14 & 3.132 & 12.26 & 1315 & 11.78 & 84.14 \\
G14 & 100 & 0.22 & 1.401 & 4.90 & 1255 & 4.65 & 21.13 \\
G15 & 100 & 0.22 & 2.426 & 14.71 & 1325 & 14.42 & 65.54 \\
G16 & 100 & 0.22 & 3.132 & 24.52 & 1390 & 22.27 & 101.22 \\
G17 & 200 & 0.31 & 1.401 & 9.81 & 1270 & 9.75 & 31.45 \\
G18 & 200 & 0.31 & 2.426 & 29.43 & 1370 & 27.63 & 89.12 \\
G19 & 200 & 0.31 & 3.132 & 49.05 & 1410 & 45.72 & 147.48 \\
\hline
\end{tabular}




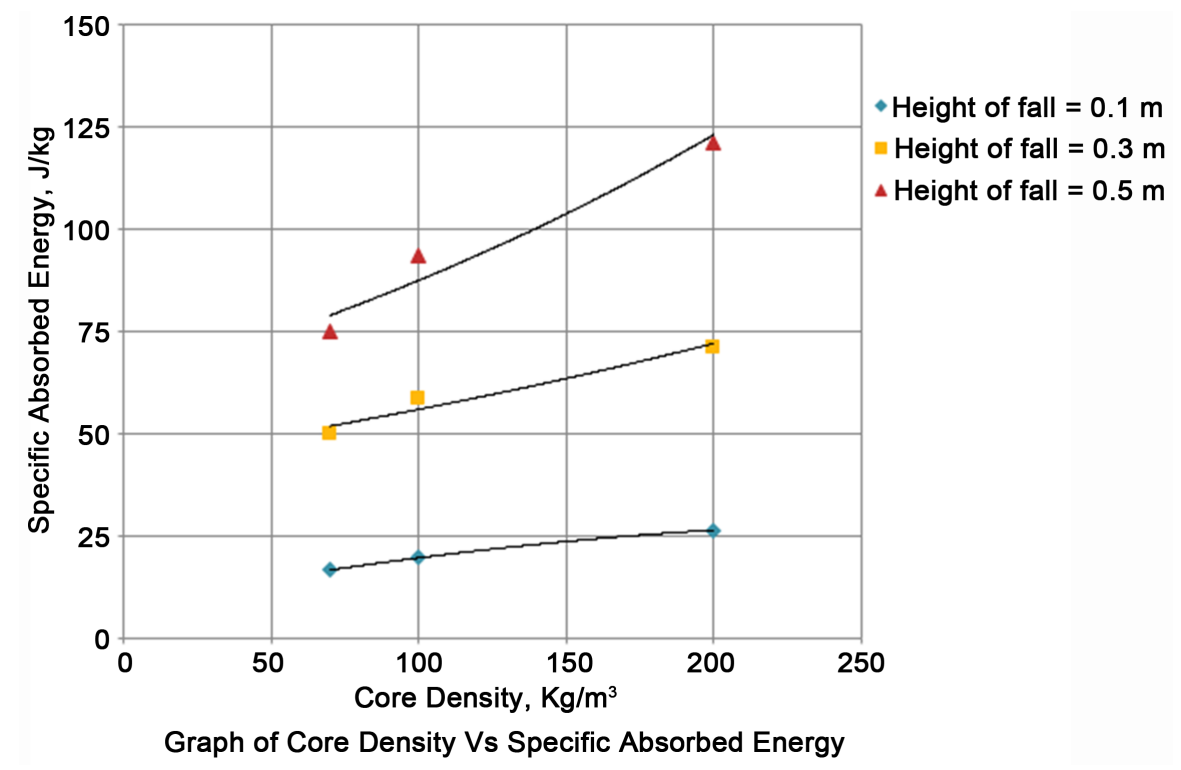

Figure 6. $10 \mathrm{~mm}$ core thickness specific absorbed energy.

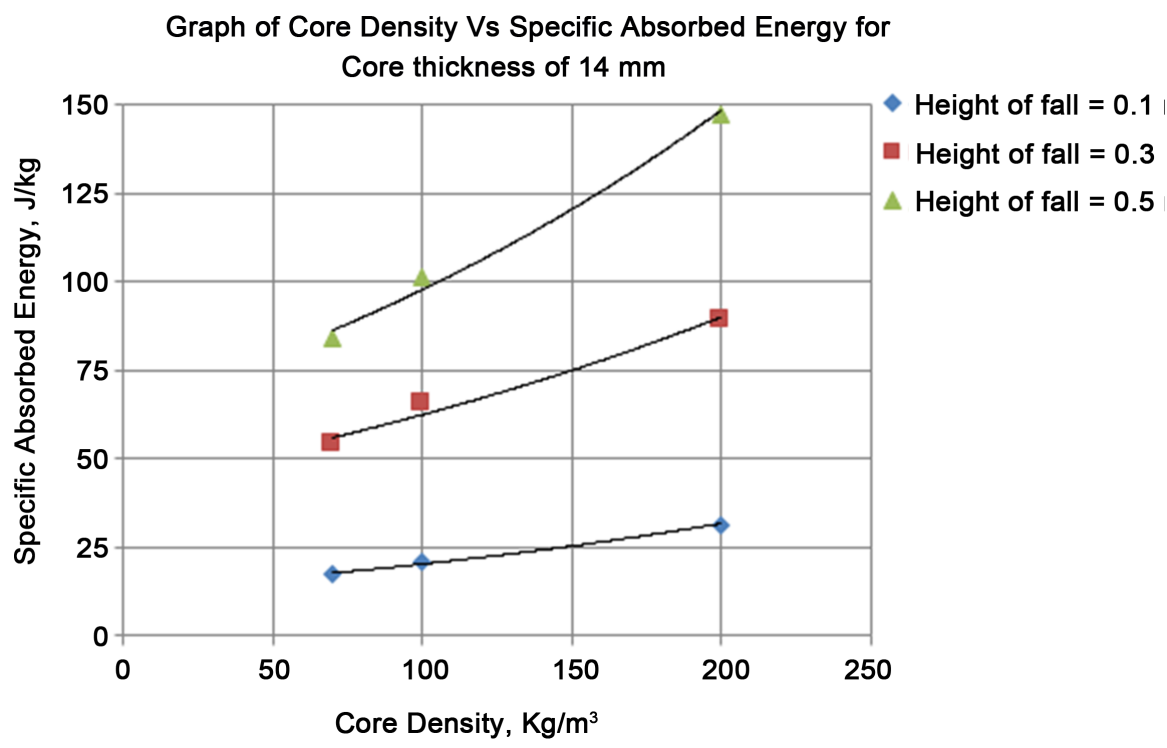

Figure 7. $14 \mathrm{~mm}$ core thickness specific absorbed energy.

As expected, the sandwich panels with denser core results in higher energy absorption. For a range of densities tested in this experimental study, the specific energy absorption and impact energy factor are almost proportional to the core density. Moreover, the global bending of sandwich panels with denser cores seemed to be more obvious due to the higher resistant to deformation of the denser foam. These phenomena occurs because that higher density foam would give a better distribution of load throughout the area when subjected to load, which would lead to a lower localized mean load.

\section{Conclusion}

This study successfully investigates the effect of variation of core density and core thickness on specific energy absorption capacity. With increase in core density, higher energy absorption was noticed similar to variation of core thickness. The foam core density of $200 \mathrm{Kg} / \mathrm{m}^{3}$ sandwich panel with fall of $0.5 \mathrm{~m}$ height showed maximum energy absorption. 


\section{Acknowledgements}

The authors would like to thank the Management, Principal and Head of the Department of Mechanical Engineering, of their respective institutions for their support in carrying out this research work.

\section{References}

[1] Carlsson, L.A. and Kardomateas, G.A. (2011) Structural and Failure Mechanics of Sandwich Composites. Solid Mechanics and Its Applications, 121, Online.

[2] Kiratisaevee, H. and Cantwell, W.J. (2005) Low-Velocity Impact Response of High-Performance Aluminum Foam Sandwich Structures. Journal of Reinforced Plastics and Composites, 24, 1057-1072. http://dx.doi.org/10.1177/0731684405048205

[3] Hazizan, M.A. and Cantwell, W.J. (2003) The Low Velocity Impact Response of an Aluminium Honeycomb Sandwich Structure. Composites Part B: Engineering, 34, 679-687. http://dx.doi.org/10.1016/S1359-8368(03)00089-1

[4] Zhao, H., Elnasri, I. and Girard, Y. (2007) Perforation of Aluminium Foam Core Sandwich Panels under Impact Loading-An Experimental Study. International Journal of Impact Engineering, 34, 1246-1257. http://dx.doi.org/10.1016/j.ijimpeng.2006.06.011

[5] Ashby, M.F., Evans, A.G., Fleck, N.A., et al. (2000) Metal Foams: A Design Guide. Butterworth Heinemann, Boston.

[6] Ruan, D., Lu, G. and Wong, Y.C. (2010) Quasi-Static Indentation Tests on Aluminium Foam Sandwich Panels. Composite Structures, 92, 2039-2046. http://dx.doi.org/10.1016/j.compstruct.2009.11.014

[7] Abrate, S. (1998) Impact on Composite Structures. Cambridge University Press, Cambridge. http://dx.doi.org/10.1017/CBO9780511574504

[8] Villanueva, G.R. and Cantwell, W.J. (2004) The High Velocity Impact Response of Composite and FML-Reinforced Sandwich Structures. Composites Science and Technology, 64, 35-54. http://dx.doi.org/10.1016/S0266-3538(03)00197-0

[9] Roach, A.M., Evans, K.E. and Jones, N. (1998) The Penetration Energy of Sandwich Panel Elements under Static and Dynamic Loading. Part I. Composite Structures, 42, 119-134. http://dx.doi.org/10.1016/S0263-8223(98)00061-0

[10] Liaghat, G.H., Alavinia, A., Daghyani, H.R. and Sadighi, M. (2010) Ballistic Limit Evaluation for Impact of Cylindrical Projectiles on Honeycomb Panels. Thin-Walled Structures, 48, 55-61. http://dx.doi.org/10.1016/j.tws.2009.07.008

[11] Leijten, J., Bersee, H.E.N., Bergsma, O.K. and Beukers, A. (2009) Experimental Study of the Low-Velocity Impact Behavior of Primary Sandwich Structures in Aircraft. Composites Part A: Applied Science and Manufacturing, 40, 164-175.

[12] Flores-Johnson, E.A. and Li, Q.M. (2011) Experimental Study of the Indentation of Sandwich Panels with Carbon Fibre-Reinforced Polymer Face Sheets and Polymeric Foam Core. Composites Part B: Engineering, 42, 1212-1219. http://dx.doi.org/10.1016/j.compositesb.2011.02.013

[13] Schubel, P.M., Luo, J.J. and Daniel, I.M. (2005) Low Velocity Impact Behavior of Composite Sandwich Panels. Composites Part A: Applied Science and Manufacturing, 36, 1389-1396. http://dx.doi.org/10.1016/j.compositesa.2004.11.014

[14] Hayman, B. (2007) Approaches to Damage Assessment and Damage Tolerance for FRP Sandwich Structures. Journal of Sandwich Structures and Materials, 9, 571-596. http://dx.doi.org/10.1177/1099636207070853

[15] Nasirzadeh, R. and Sabet, A.R. (2014) Study of Foam Density Variations in Composite Sandwich Panels under High Velocity Impact Loading. International Journal of Impact Engineering, 63, 129-139. http://dx.doi.org/10.1016/j.ijimpeng.2013.08.009

[16] Linul, E., Şerban, D.A., Voiconi, T., Marşavina, L. and Sadowski, T. (2014) Energy-Absorption and Efficiency Diagrams of Rigid PUR Foams. Key Engineering Materials, 601, 246-249. http://dx.doi.org/10.4028/www.scientific.net/KEM.601.246

[17] Apostol, D.A. and Constantinescu, D.M. (2012) Influence of Speed of Testing and Temperature on the Behaviour of Polyurethane Foams. Revue Roumaine des Sciences, 1, 73-75. 